\title{
TITLE:
}

\section{Decomposition behavior of woody biomass in water-added supercritical methanol}

\author{
$\operatorname{AUTHOR}(\mathrm{S}):$
}

Minami, Eiji; Saka, Shiro

\section{CITATION:}

Minami, Eiji ...[et al]. Decomposition behavior of woody biomass in water-added supercritical methanol. Journal of Wood Science 2005, 51: 395-400

\section{ISSUE DATE:}

2005-08

URL:

http://hdl.handle.net/2433/250162

\section{RIGHT:}

This is a post-peer-review, pre-copyedit version of an article published in Journal of Wood Science. The final authenticated version is available online at: http://dx.doi.org/10.1007/s10086-004-0670-y. この論文は出版社版であり ません。引用の際には出版社版をご確認ざ利用ください。; This is not the published version. Please cite only the published version. 


\section{Title page}

Type of Article : Original article

Title :

Decomposition behavior of woody biomass in water-added supercritical methanol

Authors :

Eiji Minami, Shiro Saka

Eiji Minami, Shiro Saka( $\bowtie)$

Department of Socio-Environmental Energy Science, Graduate School of Energy

Science, Kyoto University, Yoshida-honmachi Sakyo-ku, Kyoto, 606-8501, Japan

Tel/Fax : +81-(0) 75-753-4738

E-mail : saka@energy.kyoto-u.ac.jp

Keywords : supercritical methanol, Japanese beech, Fagus crenata, lignin, cellulose 


\section{Abstract}

The chemical conversion of Japanese beech (Fagus crenata Blume) in water-added supercritical methanol was studied in a wide range of water content using a batch-type reaction vessel to obtain chemicals from lignocellulosics. It was consequently found that an addition of water enhanced the decomposition of wood cell wall components; cellulose, hemicelluloses and lignin. In the high water content, however, it resulted in a lower solubility for lignin-derived products causing an increase in the mass of the residue. The water content was, thus, optimized to be around $10 \mathrm{vol} \%$ for the decomposition of wood. Concomitantly, the yield and selectivity of the chemicals from wood could be regulated by the addition of water, especially for the lignin-derived products. As a result, the monomeric compounds of lignin, coniferyl alcohol and sinapyl alcohol, were recovered as their $\gamma$-methyl ethers in higher yields than those without addition of water. 


\section{Introduction}

In our present environmental situations, including global warming, acid rain and exhaustion of fossil resources, biomass resources that are renewable, carbon-neutral and remarkably massive in amount on the earth will become more important as alternatives to fossil resources. According to our recent survey, about 360 million tonnes of biomass resources are annually generated in Japan, of which 76 million tonnes are unutilized. ${ }^{1}$ The latter value is enormous and equivalent to about $11 \%$ of the carbon dioxide emitted in 1990 in Japan. Therefore, technologies that can convert them to valuable liquid fuels and chemicals will be important for mitigating our energy and environmental problems. For the chemical conversion of biomass resources, recently, the use of supercritical fluid has been thought to be attractive due to its unique properties.

Supercritical water $\left(>374^{\circ} \mathrm{C},>22.1 \mathrm{MPa}\right)$ has the lower dielectric constant and higher ionic product than those of liquid water at ambient conditions, whose values can be continuously varied by regulating temperature and pressure. ${ }^{2-5}$ The supercritical (or near-critical) water treatment of cellulose has been studied by various groups to obtain hydrolysis products for a subsequent alcohol fermentation. ${ }^{6-14}$ In these cases, although the pyrolysis was found to be depressed by controlling the reaction conditions, hydrolysis products such as glucose were further decomposed rapidly due to the high critical temperature of water.

On the other hand, the critical temperature $\left(T_{\mathrm{c}}=239^{\circ} \mathrm{C}\right)$ and critical pressure $\left(P_{c}=8.09 \mathrm{MPa}\right)$ of methanol, which are lower than those of water, offer milder conditions for the reaction. In supercritical methanol, therefore, side reactions caused by pyrolysis are expected to be depressed. In addition, the dielectric constant of liquid 
methanol at ambient conditions is about 32, which makes moderate solubility for many kinds of polar and electrolytic substances as well as low-polar substances. In turn, it lowers to be about 7 at critical point, ${ }^{5}$ whose value is equivalent to that of typical non-polar organic solvents, and it can dissolve many kinds of non-polar organic substances and inorganic gases. Therefore, the use of methanol as a solvent for the supercritical fluid treatment is expected to dissolve well relatively high-molecular-weight products from cellulose, hemicelluloses and lignin.

Actually, McDonald et al. and Poirer et al. reported a good conversion of wood to liquefied products by supercritical methanol treatment. ${ }^{15,16}$ Ishikawa and Saka studied the treatment of cellulose samples including avicel (microcrystalline cellulose), cotton linters and dissolving pulp, and reported that the cellulose could be decomposed by methanolysis producing methyl glucosides. ${ }^{17}$ Minami and Saka also studied the treatment of hardwood and softwood and reported that all cell wall components of wood, cellulose, hemicelluloses and lignin, were decomposed and liquefied efficiently in methanol at $350^{\circ} \mathrm{C} / 43 \mathrm{MPa} .{ }^{18}$ In these cases, however, an elongated treatment, about several tens minute, was required for the decomposition of cellulose due to its fine fibrillar and crystalline structures.

In this study, therefore, the water-added supercritical methanol treatment of woody biomass was studied to produce chemicals more efficiently with higher yields. The addition of water to methanol is expected to give high reactivity in the solvolysis caused by the higher ionic product of subcritical water, ${ }^{2}$ with relatively milder conditions of supercritical methanol. 


\section{Materials and methods}

Water-added supercritical methanol treatment

As woody biomass sample, wood flour of Japanese beech (Fagus crenata Blume) passed with 80 mesh (about $280 \mu \mathrm{m}$ in passing size) was subjected to water-added supercritical methanol treatment. High-performance liquid chromatography (HPLC)-grade methanol and distilled water were used as solvents. The treatment was conducted using a batch-type supercritical fluid biomass conversion system. ${ }^{17,19}$

To start the treatment, approximately $4.9 \mathrm{~mL}$ of methanol and water mixture was placed with $150 \mathrm{mg}$ of beech wood flour in a $5 \mathrm{~mL}$ reaction vessel. The water content (water/(water+methanol)) was ranged from 0 to 100 in volumetric percentage (vol\%). The reaction vessel was then immersed in a molten tin bath preheated to $270^{\circ} \mathrm{C}$ or $350^{\circ} \mathrm{C}$. Typical time courses of the temperature and pressure in the vessel are shown in previous work. ${ }^{12,17}$

After the treatment for 1 30 min, an obtained reaction mixture was filtered with a $0.2 \mu \mathrm{m}$ membrane filter to separate water/methanol-soluble portion and water/methanol-insoluble residue. The residue includes hydrophobic oily substances especially in case of high water content as in a similar manner of the supercritical water treatment of wood. ${ }^{14}$ Therefore, the water/methanol-insoluble residue was washed with $10 \mathrm{~mL}$ of methanol to recover the oily substances as methanol-soluble portion and remaining residue was referred to as methanol-insoluble residue, whose masses were weighed after drying, respectively. 
Analytical methods

The water/methanol-soluble and methanol-soluble portions were directly analyzed by HPLC carried out with a Shimadzu LC-10A system under the following conditions: 1) column, STR ODS-II; flow rate, $1.0 \mathrm{~mL} / \mathrm{min}$; eluent, $\mathrm{CH}_{3} \mathrm{OH} / \mathrm{H}_{2} \mathrm{O} 20 / 80 \rightarrow 100 / 0$ ( $0 \rightarrow 60 \mathrm{~min})$; detector, ultraviolet light (UV, $\lambda=280 \mathrm{~nm})$; temperature, $\left.40^{\circ} \mathrm{C} .2\right)$ Column, ULTRON PS-80P; flow rate, $0.8 \mathrm{~mL} / \mathrm{min}$; eluent, $\mathrm{H}_{2} \mathrm{O}$; detector, refractive index detector (RID); temperature, $80^{\circ} \mathrm{C}$. Gel permeation chromatography (GPC) was also carried out for the water/methanol-soluble and methanol-soluble portions with the same system under the following conditions: column, Shodex KF-801 connected with KF-802, KF-802.5 and KF-803 in the series; flow rate, $0.6 \mathrm{~mL} / \mathrm{min}$; eluent, tetrahydrofuran (THF); detector, UV(280nm) and RID; temperature, $50^{\circ} \mathrm{C}$.

For the methanol-insoluble residue, the Klason lignin content and acid-soluble lignin were determined according to the described method. ${ }^{20}$ In addition, the amounts of constituent monosaccharides from the methanol-insoluble residue were determined by HPLC analysis for the clear filtrate from acid hydrolyzates in the Klason lignin determination under the conditions mentioned above. The cellulose and hemicelluloses contents in the methanol-insoluble residue were then estimated based on the amounts of glucose and other monosaccharides, respectively. 


\section{Results and discussion}

Decomposition behavior of wood in water-added supercritical methanol

Figure 1 shows the changes in the each fraction from beech wood as a function of water content as treated at $350^{\circ} \mathrm{C}$ for $5 \mathrm{~min}$. Under the presence of water, decomposition and liquefaction of wood proceeded efficiently and the methanol-insoluble residue became lesser than that without water (0vol\%). The residue decreased with an increase of water and around 10vol\% of water content resulted in a minimum value in mass fraction. In turn, however, both of methanol-soluble portion and methanol-insoluble residue increased gradually as the water content was further increased. According to the study of the supercritical water treatment of wood, ${ }^{14}$ the methanol-soluble portion mainly consists of lignin-derived products. Similarly, the methanol-soluble portion obtained in this study was always found to include only lignin-derived products by HPLC analysis.

Figure 2 shows the molecular weight distributions of the water/methanol-soluble and methanol-soluble portions by GPC analysis. In case without water, the distribution of water/methanol-soluble portion was ranged from about 3000 to less than 162 in the polystyrene standard molecular weight. With an increase of water content, however, a part of higher molecular weight fractions in the water/methanol-soluble portion decreased gradually and transferred conversely to the methanol-soluble portion. This result indicates that the increase of methanol-soluble portion shown in Figure 1 is caused by the decrease in solubility of the lignin-derived products due to high polarity of water. Concomitantly, the increase of methanol-insoluble residue should be originated in the higher-molecular-weight oily 
substances from lignin, which could not diffuse into the mixture of methanol and water.

After all, the optimum water content was found to be around $10 \mathrm{vol} \%$ for the decomposition and liquefaction of woody biomass at the condition of $270^{\circ} \mathrm{C}$ as well as $350^{\circ} \mathrm{C}$. In the following study, therefore, the water content was set to be $10 \mathrm{vol} \%$. In this case, the amount of methanol-soluble portion was very small as shown in Figure 1 so that it was assumed to be null.

Figure 3 shows the changes in the methanol-insoluble residues as a function of the treatment time. Under the condition of $270^{\circ} \mathrm{C}$ without water, the residue remained constant after 5 min of the treatment and about $65 \%$ of the residue was recovered for $30 \mathrm{~min}$. Even though, in the presence water, the residue was lesser than that in case without water, the methanol-insoluble residue also remained constant after 5 min of the treatment. Regarding the cell wall components, Figures 4 (a) and (b) show the changes in the chemical composition of cellulose, hemicelluloses and lignin in the methanol-insoluble residue treated at $270^{\circ} \mathrm{C}$ without water and $10 \mathrm{vol} \%$ of water, respectively. It was found that the lignin treated with $10 \mathrm{vol} \%$ of water was liquefied to a greater extent than that without water. More apparent trend was observed in the conversion of hemicelluloses. In case without water, 16wt\% of hemicelluloses remained in the residue even after the treatment for $30 \mathrm{~min}$, whereas, with $10 \mathrm{vol} \%$ of water, hemicelluloses disappeared completely for $30 \mathrm{~min}$. In this way, the addition of small amount of water enhanced the decomposition of lignin and hemicelluloses, which should be caused by the acidic character of subcritical water. On the other hand, however, cellulose was not decomposed under the given condition in both cases. This observed difference between hemicelluloses and cellulose possibly originates from the differences in their molecular structures; hemicelluloses are in amorphous form, 
whereas cellulose is in crystalline form. Therefore, hemicelluloses are more accessible to molecules of methanol and water than cellulose.

At the condition of $350^{\circ} \mathrm{C}$, however, more than $90 \mathrm{wt} \%$ of wood was liquefied eventually in both cases as shown in Figure 3. This result indicates that the cellulose in wood was decomposed efficiently in water/methanol under such a high temperature. As shown in Figures 5 (a) and (b), cellulose was liquefied efficiently in water/methanol at the temperature of $350^{\circ} \mathrm{C}$. Under the presence of water, moreover, the cellulose was liquefied completely after 5 min of the treatment, while more than 30 min of the treatment was required in case without water. It implies that the crystalline structure of cellulose can be relaxed in such a high temperature, and once that occurs, the water also enhances the decomposition of cellulose. For lignin, however, about $1.5 \mathrm{wt} \%$ of the residue on the original wood basis remained constant after $3 \mathrm{~min}$ of treatment in both cases as observed in Figures 5 (a) and (b). In our previous study, the remaining lignin was characterized to be rich in condensed structures of linkages, such as aryl-aryl linkage, which are stable in supercritical methanol. ${ }^{18,21,22}$

Chemicals from wood in water/methanol-soluble portion

\section{Lignin-derived products}

According to the proposed degradation pathway of lignin in supercritical methanol, ${ }^{18}$ lignin can be decomposed to low-molecular-weight products by cleavage of ether linkages, and the products lower than about 3000 in molecular weight can be liquefied in methanol. After the prolonged treatment, a part of the liquefied products is further 
depolymerized into coniferyl alcohol (CA) and sinapyl alcohol (SA), which are monomeric units of guaiacyl and syringyl lignin, respectively. These are, then, converted to their $\gamma$-methyl ethers (CA- $\gamma$ and SA- $\gamma$ ) and further decomposed to isoeugenol (IE) and 2,6-dimethoxy-4-(1- propenyl)phenol (DPP), respectively.

Table 1 shows the yields of lignin-derived compounds on the original lignin basis. At the condition of $270^{\circ} \mathrm{C}$ without water, CA, SA and their $\gamma$-methyl ethers existed relatively stable during the treatment so that yields of IE and DPP were low. Therefore, CA, SA and their $\gamma$-methyl ethers were obtained in total yield of about 25 30wt\% on lignin basis but each yield of them was not high. On the other hand, in the presence of water, the decomposition of lignin proceeded efficiently and CA and SA were converted quickly so that their $\gamma$-methyl ethers were obtained in higher yields than those without water. As a result, $28.5 \mathrm{wt} \%$ of SA- $\gamma$ was recovered after the treatment for $3 \mathrm{~min}$. However, the prolonged treatment resulted in further conversion of the $\gamma$-methyl ethers to IE and DPP. At the condition of $350^{\circ} \mathrm{C}$, the rapid conversion to IE and DPP was found in both cases so that about $3 \mathrm{wt} \%$ and $15 \mathrm{wt} \%$ of IE and DPP were obtained, respectively. In this way, it was found that the addition of water could regulate the yields and selectivity of the producing compounds from lignin during the supercritical methanol treatment of wood. The value of $28.5 \mathrm{wt} \%$ of sinapyl alcohol $\gamma$-methyl ether was, actually, the same level in yield as that of syringaldehyde from the alkaline nitrobenzene oxidation of wood..$^{23}$

\section{Cellulose-derived products}

According to the decomposition pathway of cellulose proposed previously, ${ }^{17}$ methanolysis of cellulose in supercritical methanol resulted in methylated 
cello-oligosaccharides, such as methylated cellotriose and cellobiose, which are converted to methyl $\beta$-D-glucoside (MG- $\beta$ ) and methyl $\alpha$-D-glucosides (MG- $\alpha$ ). Subsequently, these were anomerized and as the treatment was prolonged, these were decomposed further to other products, such as levoglucosan (LG) and 5-hydroxymethylfurfural (5-HMF).

Table 2 shows the yields of cellulose-derived compounds on the original cellulose basis. At the conditions of $350^{\circ} \mathrm{C}$ and $0 \mathrm{vol} \%$ of water, methyl glucosides were found in about $15 \mathrm{wt} \%$ of the total yield after $30 \mathrm{~min}$ of the treatment but not produced at the first stage of the reaction. Besides, in case with water, although the methyl glucosides were further decomposed to other products, such as 5-HMF, they were produced even in shorter reaction times. In this way, the addition of water could also regulate the yields of the producing compounds from cellulose, as well as lignin. At the conditions of $350^{\circ} \mathrm{C}$ and $5 \mathrm{vol} \%$ of water, actually, $6.1 \mathrm{wt} \%$ of MG- $\beta$ and $9.9 \mathrm{wt} \%$ of MG- $\alpha$ were found after the treatment for $5 \mathrm{~min}$, whose values were slightly higher than those in case without water.

\section{Conclusion}

The decomposition behavior of wood during water-added supercritical methanol treatment was studied to obtain chemicals from lignocellulosics. It was found that the addition of water enhanced the decomposition of cellulose, hemicelluloses and lignin even though the higher water content resulted in the lower solubility for the high-molecular-weight products from lignin causing an increase of the methanol-insoluble residue. The optimum water content for the conversion of woody 
biomass to the liquefied products was, thus, found to be around $10 \mathrm{vol} \%$. As a result, under the condition of $350^{\circ} \mathrm{C}$, more than $95 \mathrm{wt} \%$ of beech wood was decomposed in water/methanol mixture after the treatment for $5 \mathrm{~min}$. In addition, yield and selectivity of the chemicals from both cellulose and lignin could be regulated by the addition of water. Overall, by the treatment with water-added supercritical methanol, chemicals such as coniferyl alcohol $\gamma$-methyl ether, sinapyl alcohol $\gamma$-methyl ether and methyl glucosides could be obtained rather efficiently. Especially, sinapyl alcohol $\gamma$-methyl ether was recovered in a high yield of $28.5 \mathrm{wt} \%$ on lignin basis. 


\section{Acknowledgments}

This research has been done under the research program for development of technologies for establishment of eco-system based on recycling in rural villages for the 21st century (April 2000 ) from the Ministry of Agriculture, Forestry and Fisheries, Japan, and by the Kyoto University 21 COE program “Establishment of COE on Sustainable Energy System” (April 2002 ) from the Ministry of Education, Culture, Sports, Science and Technology, Japan. 


\section{References}

1. Minami E, Saka S (2004) Biomass resources present in Japan - Annual quantities grown, unused and wasted. Biomass and Bioenergy (in press)

2. Holzapfel W (1969) Effect of pressure and temperature on the conductivity and ionic dissoziation of water up to $100 \mathrm{kbar}$ and $1000^{\circ} \mathrm{C}$. J Chem Phys $50: 4424-4428$

3. Franck EU (1970) Water and aqueous solutions at high pressures and temperatures. Pure Appl Chem 24:13-29

4. Tester JW, Holgate HR, Armellini FJ, Webley PA, Killilea WR, Hong GT, Barner HE (1993) Supercritical water oxidation technology: process development and fundamental research. ACS Symp Series 518:35-76

5. Franck EU, Deul R (1978) Dielectric behavior of methanol and related polar fluids at high pressures and temperatures. Faraday Disc of the Chem Soc 66:191-198

6. Antal MJ Jr, Mok WSL, Richards GN (1990) Four-carbon model compounds for the reactions of sugars in water at high temperature. Carbohydr Res 199:111-115

7. Sakaki T, Shibata M, Miki T, Hirosue H, Hayashi N (1996) Decomposition of cellulose in near-critical water and fermentability of the products. Energy and Fuels 10:684-688

8. Sakaki T, Shibata M, Miki T, Hirosue H, Hayashi N (1996) Reaction model of cellulose decomposition in near-critical water and fermentation of products. Bioresour. Technol. 58:197-202

9. Sasaki M, Kabyemela B, Malaluan R, Hirose S, Takeda N, Adschiri T, Arai K 
(1998) Cellulose hydrolysis in subcritical and supercritical water. J

Supercritical Fluids 13:261-268

10. Sasaki M, Fang Z, Fukushima Y, Adschiri T, Arai K (2000) Dissolution and hydrolysis of cellulose in subcritical and supercritical water. Ind Eng Chem Res 39:2883-2890

11. Saka S, Ueno T (1999) Chemical conversion of various celluloses to glucose and its derivatives in supercritical water. Cellulose 6:177-191

12. Saka S, Konishi R (2001) Chemical conversion of biomass resources to useful chemicals and fuels by supercritical water treatment. In: Bridgwater AV (ed) Progress in Thermochemical Biomass Conversion. Blackwell Sci, Oxford, pp $1338-1348$

13. Ehara K, Saka S (2002) A comparative study on chemical conversion of cellulose between the batch-type and flow-type systems in supercritical water. Cellulose 9:301-311

14. Ehara K, Saka S, Kawamoto H (2002) Characterization of the lignin-derived products from wood as treated in supercritical water. J Wood Sci 48:320-325

15. McDonald EC, Howard J, Bennett B (1983) Chemicals from forest products by supercritical fluid extraction. Fluid Phase Equilib 10:337-344

16. Poirier MG, Ahmed A, Grandmaison JL, Kaliaguine CF (1987) Supercritical gas extraction of wood with methanol in a tubular reactor. Ind Eng Chem Res $26: 1738-1743$

17. Ishikawa Y, Saka S (2001) Chemical conversion of cellulose as treated in supercritical methanol. Cellulose 8:189-195

18. Minami E, Saka S (2002) A comparative study of decomposition behaviors between hardwood and softwood in supercritical methanol. J Wood Sci 
49:73-78

19. Kusdiana D, Minami E, Ehara K, Saka S (2002) Development of the batch-type and flow-type supercritical fluid biomass conversion systems. In: Proceedings of 12th European Conference and Technology Exhibition on Biomass for Energy, Industry and Climate Protection, Amsterdam, pp 789-792

20. Dence CW (1992) The Determination of Lignin. In: Lin SY, Dence CW (eds) Methods in Lignin Chemistry. Springer-Verlag, Berlin, pp 33-39

21. Tsujino J, Kawamoto H, Saka S (2003) Reactivity of lignin in supercritical methanol studied with various lignin model compounds. Wood Sci Technol 37:299-307

22. Minami E, Kawamoto H, Saka S (2003) Reaction behavior of lignin in supercritical methanol as studied with lignin model compounds. J Wood Sci 49:158-165

23. Chen CL (1992) Nitrobenzene and Cupric Oxide Oxidations. In: Lin SY, Dence CW (eds) Methods in Lignin Chemistry. Springer-Verlag, Berlin, pp $301-312$ 
Table 1. Yields of lignin-derived products from beech wood as treated in various conditions of the water-added supercritical methanol.

\begin{tabular}{|c|c|c|c|c|c|c|}
\hline \multirow[t]{3}{*}{ Reaction condition } & \multicolumn{6}{|c|}{ Yield (wt\% on lignin basis) } \\
\hline & \multicolumn{3}{|c|}{ Guaiacyl lignin } & \multicolumn{3}{|c|}{ Syringyl lignin } \\
\hline & CA & CA- $\gamma$ & IE & SA & SA- $\gamma$ & DPP \\
\hline \multicolumn{7}{|l|}{ a) Without water } \\
\hline $270^{\circ} \mathrm{C} / 3 \mathrm{~min}$ & 2.9 & 1.8 & 0.0 & 12.9 & 6.0 & 0.0 \\
\hline $5 \mathrm{~min}$ & 2.3 & 3.7 & 0.14 & 9.1 & 11.4 & 0.67 \\
\hline $10 \mathrm{~min}$ & 1.2 & 5.8 & 0.18 & 10.0 & 12.5 & 1.2 \\
\hline $30 \min$ & 0.76 & 2.5 & 0.58 & 7.8 & 10.5 & 3.5 \\
\hline $350^{\circ} \mathrm{C} / 1 \mathrm{~min}$ & 1.8 & 2.59 & 1.6 & 17.2 & 8.2 & 4.7 \\
\hline $3 \mathrm{~min}$ & 0.0 & 0.47 & 1.8 & 1.7 & 1.7 & 15.3 \\
\hline $5 \mathrm{~min}$ & 0.0 & 0.27 & 1.7 & 0.34 & 0.27 & 14.8 \\
\hline $10 \mathrm{~min}$ & 0.0 & 0.0 & 2.3 & 0.25 & 0.0 & 14.8 \\
\hline \multicolumn{7}{|l|}{ b) With water, 10vol\% } \\
\hline $270^{\circ} \mathrm{C} / 3 \mathrm{~min}$ & 1.3 & 5.8 & 1.1 & 4.1 & 28.5 & 3.8 \\
\hline $5 \mathrm{~min}$ & 1.4 & 4.7 & 1.5 & 3.1 & 22.0 & 6.1 \\
\hline $10 \mathrm{~min}$ & 0.61 & 2.5 & 1.6 & 3.0 & 8.5 & 8.1 \\
\hline $30 \mathrm{~min}$ & 0.0 & 0.0 & 2.2 & 0.0 & 0.0 & 11.2 \\
\hline $350^{\circ} \mathrm{C} / 1 \mathrm{~min}$ & 0.0 & 1.1 & 2.4 & 0.0 & 3.5 & 12.9 \\
\hline $3 \mathrm{~min}$ & 0.0 & 0.0 & 2.9 & 0.0 & 0.0 & 15.1 \\
\hline $5 \mathrm{~min}$ & 0.0 & 0.0 & 3.8 & 0.0 & 0.0 & 14.4 \\
\hline $10 \min$ & 0.0 & 0.0 & 1.6 & 0.0 & 0.0 & 7.1 \\
\hline
\end{tabular}

CA, coniferyl alcohol; CA- $\gamma$, coniferyl alcohol $\gamma$-methyl ether; IE, isoeugenol; SA, sinapyl alcohol; SA- $\gamma$, sinapyl alcohol $\gamma$-methyl ether; DPP, 2,6-dimethoxy-4-(1-propenyl)phenol 
Table 2. Yields of cellulose-derived products from beech wood as treated in various conditions of the water-added supercritical methanol.

\begin{tabular}{rccccc}
\hline \multicolumn{1}{l}{ Reaction condition } & \multicolumn{5}{c}{ Yield (wt\% on cellulose basis) } \\
\cline { 2 - 6 } & MG- $\beta$ & MG- $\alpha$ & LG & 5-HMF & Fur \\
\hline \hline a) Without water & & & & & \\
$350^{\circ} \mathrm{C} / 5 \mathrm{~min}$ & trace & trace & trace & 0.46 & 0.32 \\
$10 \mathrm{~min}$ & 1.6 & 3.2 & 7.6 & 0.47 & 0.31 \\
$20 \mathrm{~min}$ & 3.7 & 6.6 & 5.4 & 0.37 & 0.21 \\
$30 \mathrm{~min}$ & 5.4 & 9.0 & 5.0 & 0.57 & 0.27 \\
\hline b) With water, 10vol\% & & & & & \\
$350^{\circ} \mathrm{C} / 1 \mathrm{~min}$ & 0.89 & 2.8 & 0.0 & 0.83 & 0.26 \\
$3 \mathrm{~min}$ & 3.0 & 3.8 & 2.8 & 1.5 & 0.28 \\
$5 \mathrm{~min}$ & 1.6 & 1.8 & 2.4 & 0.72 & 0.20 \\
$10 \mathrm{~min}$ & 0.0 & 0.0 & 0.0 & 0.08 & 0.20 \\
\hline
\end{tabular}

MG- $\beta$, methyl $\beta$-D-glucoside; MG- $\alpha$, methyl $\alpha$-D-glucoside; LG, levoglucosan; 5-HMF, 5-hydroxymethyfurfural; Fur, furfural 


\section{List of figures}

Fig. 1. Changes in the mass fraction of water/methanol-soluble portion, methanol-soluble portion and methanol-insoluble residue from beech wood treated in water-added supercritical methanol with various water contents at $350^{\circ} \mathrm{C}$ for $5 \mathrm{~min}$.

Fig. 2. GPC chromatograms of the water/methanol-soluble portion (solid lines) and methanol-soluble portion (dotted lines) from beech wood treated in water-added supercritical methanol with various water contents at $350^{\circ} \mathrm{C}$ for $5 \mathrm{~min}$. (detector, $\mathrm{UV}(\lambda=280 \mathrm{~nm}))$

Fig. 3. Changes in the residue of beech wood treated in the water-added supercritical methanol at various conditions.

Fig. 4. Product composition of beech wood treated in supercritical methanol at $270^{\circ} \mathrm{C}$ (a) without water and (b) with $10 \mathrm{vol} \%$ of water.

Fig. 5. Product composition of beech wood treated in supercritical methanol at $350^{\circ} \mathrm{C}$ (a) without water and (b) with $10 \mathrm{vol} \%$ of water. 


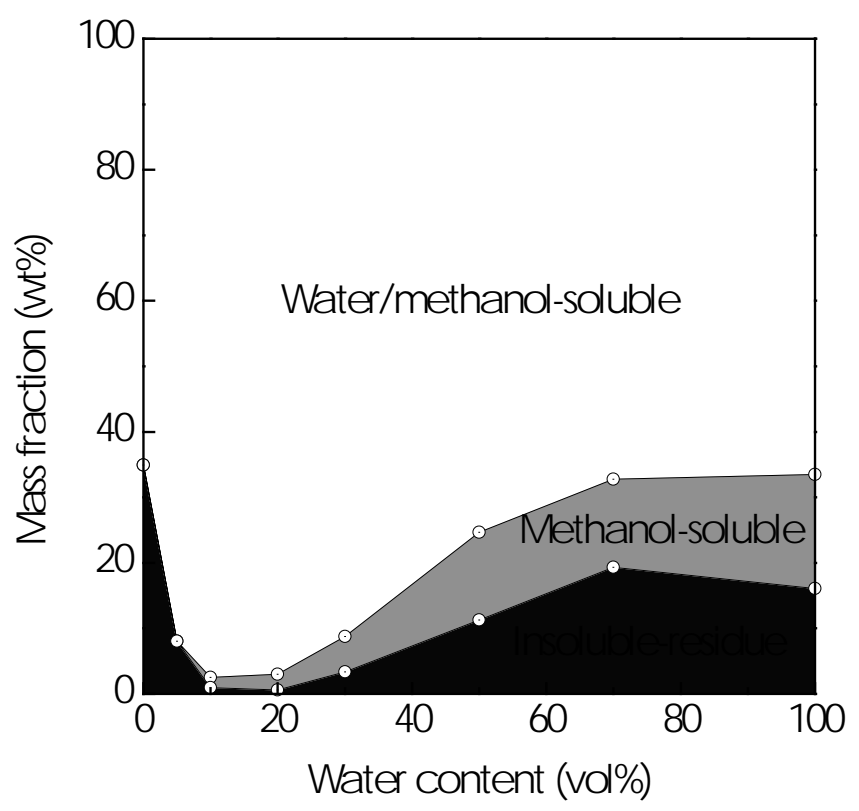




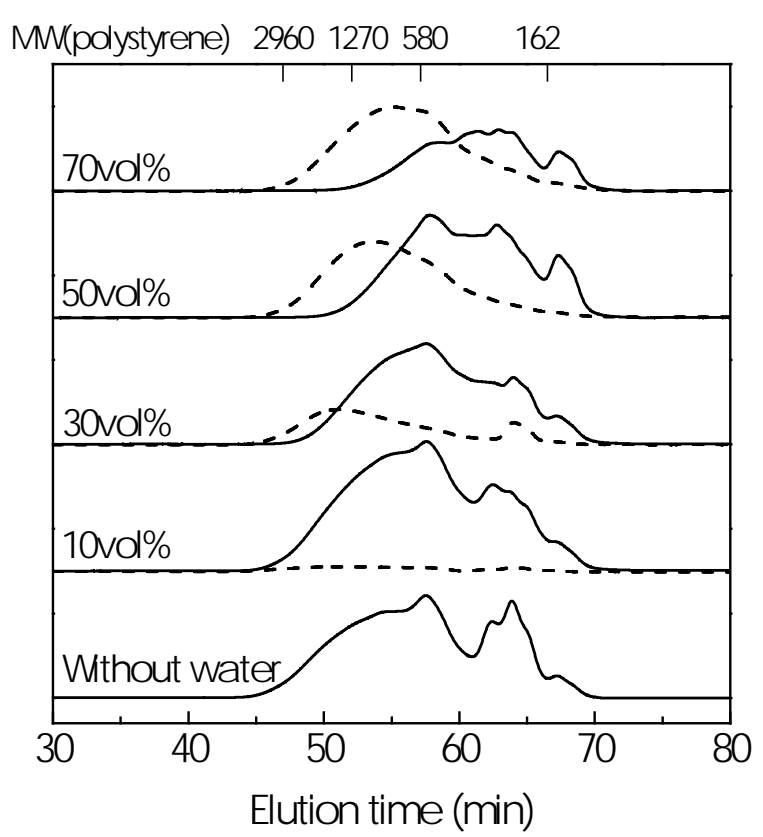




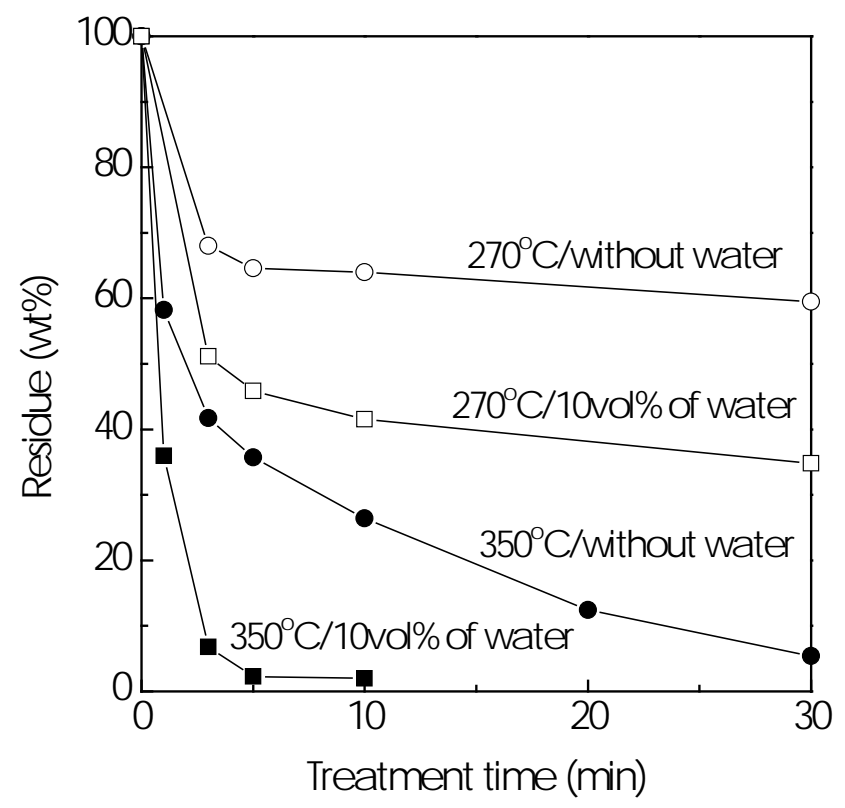




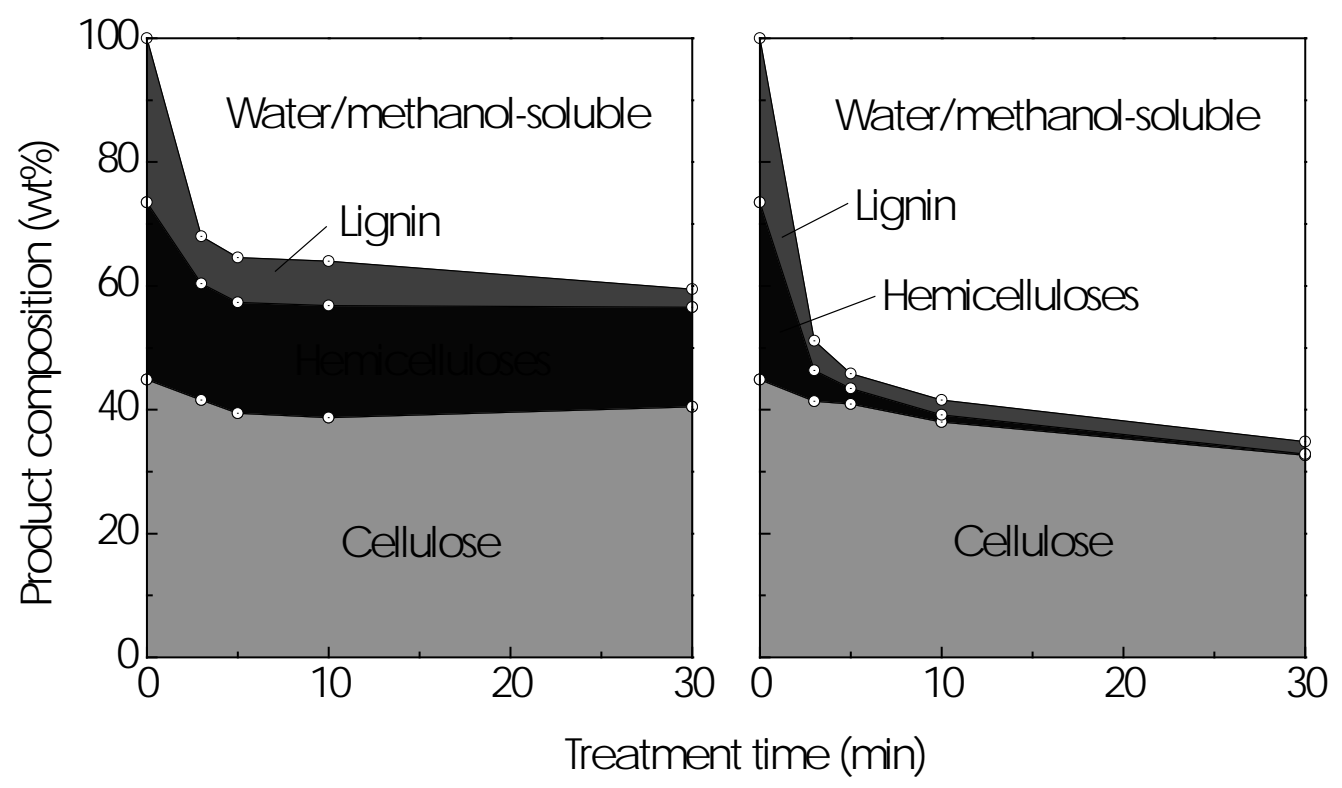

$\begin{array}{ll}\text { (a) without water } & \text { (b) with 10vol\%of water }\end{array}$ 


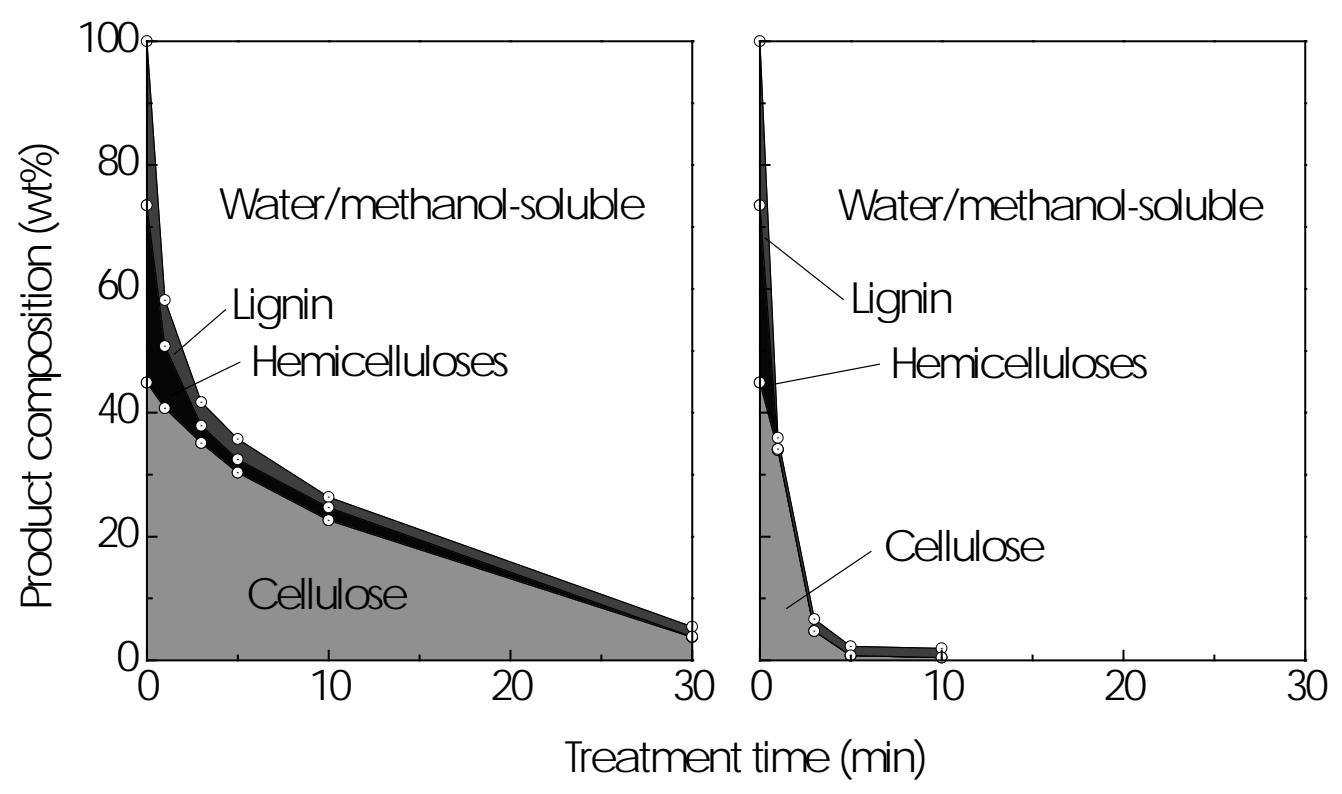

(a) without water

(b) with 10 vol\%of water 